\title{
Anticipating victory, French conservatives outline plans
}

Paris. The expected victory later this month for the conservative coalition in French elections would mean changes in the way in which research is funded and greater pressure on researchers to demonstrate the scientific value of their work. But the opposition party would preserve lifetime tenure and other features of a system inherited from the ruling Socialist party, and it has no clear plans to address the acute lack of mobility or the runaway spending on space research, the biggest problems now facing French science.

The fear among many French scientists is that a victory by the conservative opposition might undo the gains under François Mitterrand, who came to power in 1981. By increasing public spending, adding jobs and encouraging industry to invest in research, the Socialists made science a national priority (see Nature 346, 121; 1990). The policies have been sustained despite two years of harsh spending cuts under Jacques Chirac's neo-Gaullist government and the present recession; research grew from 1.97 per cent of the gross national product (GNP) in 1981 to 2.4 per cent in 1990 , putting France behind only Germany, Japan and the United States.

Alain Pompidou, science spokesman for the centre-right Union pour la Démocratie Française and the neo-Gaullist Rassemblement pour la République team, says there would be no major upheavals in research. "The imperative is not to waste time on reorganization," he says, "but to improve the existing system." Pompidou, trained as a physician, is a professor of histology at the University René Descartes in Paris, a deputy to the Minister of National Education and a member of the European Parliament. He is a likely candidate for the post of science minister in a new government.

The conservatives want to concentrate scarce resources for equipment and supplies by asking researchers to bid on the basis of detailed proposals rather than giving the money to laboratories to distribute as they please. But although some public scientists would receive less, Pompidou says, civilservant status and minimum research funding would be maintained. (Salaries account for more than three-quarters of the budget of the Centre Nationale de la Recherche Scientifique [CNRS].) At the same time, Pompidou says that not enough scientists take advantage of this security; he would like to increase competition by rewarding 'risk takers' with promotion and extra funding.

Accountability would be enhanced under a system in which projects would be evaluated "before, during and after the con- tract is signed", says Pompidou. He believes that the present four-year evaluation of laboratories is inadequate and that expensive errors are too often detected retrospectively. But there is scepticism that such a system would work, with observers saying that research organizations would have to reshape themselves into de facto research councils. In addition, the opposition's proposals to enhance productivity are unlikely to cause a widespread change if employees are guaranteed tenure for life and a modest sum for research and are not required to teach.

The conservatives' recipe for internationalization rests on a large increase in the number of postdoctoral positions for foreigners and for French researchers willing to work abroad. Pompidou also wants to improve the prospects for promotion and autonomy; he says that rigidity, not low salaries, is the greatest deterrent to bright students considering a career in science.

But the opposition's plans for more postdoctoral posts would not erase the Socialist slogan, "No more French postdocs in France". In a country proud of its policy of lifetime employment, the slogan reflects a reluctance to create a population of researchers on short-term contracts. But this reluctance has impeded the mobility of young researchers within France and the flow of talent into active research groups.

Similarly, the opposition's manifesto contains few concrete proposals on industrial research, aid to universities or disproportionate spending on space. It has presented no new plans for wealth creation, apart from vague incentives to stimulate the mobility of researchers between public research and industry. The Socialist minister for research and space, Hubert Curien, has encouraged industry to do more research through subsidies and tax credits, but after a rise in research financed by industry from 0.94 per cent of GNP in 1984 to 1.1 per cent in 1990 the growth has levelled off and fallen short of the government's target of 1.5 per cent.

Although the opposition wants to transform the centralized university system by creating autonomous research-based universities, it excludes merging the ministries of national education and research and space. But universities are unlikely to receive more research funding without such a merger. Moreover, the opposition's proposals contain none of the strongarm measures needed to make full-time researchers assume some teaching duties.

Pompidou claims that the Socialists have used secret military expenditures to overestimate increases in civil spending, the same accusation used by the Socialists in 1988

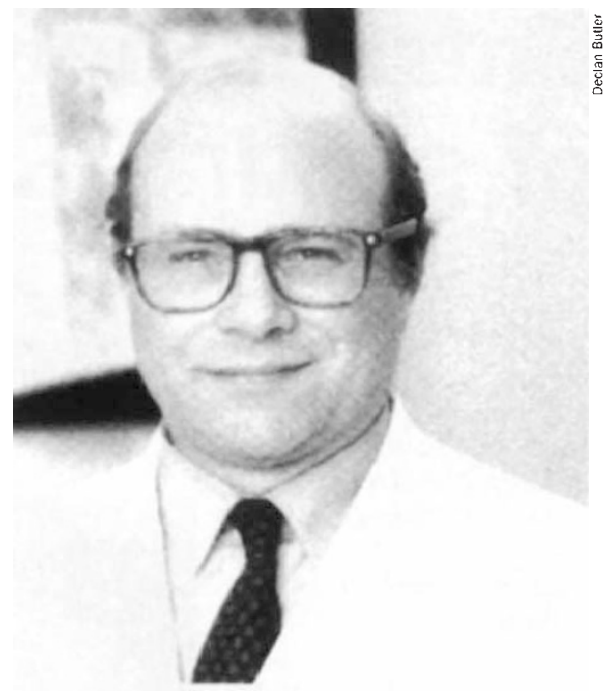

Pompidou sizes up science.

against the outgoing conservative government. But the opposition has taken no public position on the rapid growth in spending on space research, which has risen from 6.4 per cent of the civil research budget in 1982 to 18 per cent this year (see Nature 359, 659; 1992). Pompidou says that firm decisions on space spending and all other areas would come after a survey of the entire research system.

Declan Butler

\section{US plans search for ITER site}

Washington. US Department of Energy (DOE) officials expect by the end of the summer to have a plan for choosing a US candidate site for the proposed International Thermonuclear Experimental Reactor (ITER) (see Nature 358, 269; 1992). Each participant - the United States, Japan, Russia and the European Communities - has been asked to submit its choice by December 1994, with a site to be chosen by the following December.

DOE officials have yet to decide on a selection process, for example whether to limit the field to DOE's national laboratories or to hold an open competition as was done for the Superconducting Super Collider. The disadvantage of the latter ap proach, says Thomas James of the department's Office of Fusion Energy, is the time and expense of preparing a proposal that, even if selected by US officials, has only a one-in-four chance of winning. The site must also meet all US environmental and legal requirements.

At present, the ITER partners are assembling teams at the project's three joint centres in Garching (Germany), Naka (Japan) and San Diego, California. A decision on whether to proceed with building the test reactor, planned for operation as early as 2005, is not expected until at least 1996.

Tony Reichhardt 